удК 681.5.07; 655.3.062; 655.3.066.36

(ㄱ Т. Ю. Киричок, д.Т.н., професор, Я. В. Герук, аспірантка, КПІ ім. Ігоря Сікорського, В. А. Баглай,генеральний директор БМД НБУ, Київ, Україна

\title{
СИСТЕМА ФОРМУВАННЯ ЯКОСТІ ДРУКОВАНОЇ СУВЕНІРНОЇ ПРОДУКЦІЇ БАНКНОТНО-МОНЕТНИХ ДВОРІВ СВІТУ
}

\section{Проведено дослідження та аналіз сучасної друкованої} продукції Банкнотно-монетних дворів світу, їх видів, тенденції вибору тематики зображень, технологічних процесів друку та матеріалів. На основі дослідження було систематизовано критерії якості сучасної друкованої продукції Банкнотно-монетних дворів світу, що є важливим для іміджевих друкованих сувенірів більшості країн світу, а насамперед в Україні. Тому, розвиток цієї теми є сучасним, перспективним та конкурентоспроможним.

\section{Ключові слова: якісна друкована сувенірна продукція;} інтагліодрук; офорт; глибокий друк; зображення;

Банкнотно-монетний двір.

\section{Постановка проблеми}

Однією з нових тенденцій в Україні та світі постає питання виготовлення якісної іміджевої друкованої сувенірної продукції банкнотно-монетними дворами світу (БМД). Металографічний або інтагліодрук, який $є$ технологією з обмеженим доступом, або поєднання декількох технологічних процесів для друку банкнот, дають змогу виготовити автентичні друковані сувеніри, що $є$ гарним подарунком для бізнеспартнерів та об'єктом колекціонування. Це можуть бути імітації художніх творів мистецтва, виконаних у техніці гравіювання, офорту, копії цінних документів тощо.

Слід зазначити, що проблема виготовлення якісної сувенірної продукції банкнотно-монетними дворами майже не досліджена науковцями, тому $€$ актуальною та перспективною.

\section{Мета роботи}

Визначення основних критеріїв якості сучасної друкованої сувенірної продукції БМД світу та створення системи її формування.

\section{Аналіз попередніх \\ досліджень}

Якість поліграфічної продукції - це сукупність властивостей, що обумовлюють придатність продукції задовольняти певні потреби відповідно до її призначення. Якість продукції належить до числа найважливіших показників діяльності підприємства будь-якої форми власності. В умовах сучасного ринку

(c) $2018 \mathrm{p}$. 
й конкуренції вирішення проблеми якості продукції на підприємстві - це складник його іміджу, вихід не тільки на внутрішній, але й на зовнішній ринок, основа для отримання максимального прибутку та стабільного фінансового стану підприємства.

Якість друкованої продукції як економічна складова значною мірою впливає на формування таких показників, як обсяг випуску продукції, собівартість, ціна, прибуток, рентабельність залежить від надійності й точності роботи виробничого обладнання та контрольно-вимірювальної техніки, дотримання технологічних режимів, якості матеріалів, що надходять, а також об'єктивно відображає рівень застосовуваної організації виробництва й управління.

Друк ідентичних відбитків упродовж усього накладу $€$ головним завданням і технологічною умовою якісного репродукування [1]. Існують певні методи контролю якості відбитків і вимірювальна техніка. Важливим $€$ правильний вибір способу друку та подача фарби, матеріалу.

У формуванні якості поліграфічної продукції важливими $є$ виробничі заходи: технологічний процес, відповідність матеріалів, обладнання, персонал і система управління якістю ISO [2].

Основні показники якості відбитків поліграфічної продукції це оптична густина, колірні відмінності, насиченість, колірний тон, світлота, суміщення фарб, графічна точність відтворення зображення, розтискування, рівномірність розподілу фарби на відбитку [1]. Тому запорукою якісної друкованої продукції $€$ контроль зазначених показників і зіставлення 3 нормованими значеннями параметрів і їх допустимими відхиленнями. Іноді через різні відхилення видавничо-поліграфічного процесу відбуваються порушення режимів друкування й виявляються характерні дефекти відбитків: змазування штрихових елементів, подвоєння або дроблення друкувальних елементів, що розташовані окремо від загального масиву тексту або рисунка, шаблонування або збільшення довжини зображення на відбитку в напрямку його подачі в зону друкування порівняно з розмірами на формі, нерівномірність відбитка плашки, вищипування волокон паперу, виникнення муару [1]. Ці дефекти властиві всім методам друку.

Захищена продукція посідає значне місце в загальному об'ємі поліграфічного виробництва й відіграє важливу роль у економічному та суспільному розвитку держави. Для оцінки та підвищення якості необхідно правильно вимірювати й прогнозувати характеристики якості, а також вивчати залежності цих характеристик від різних факторів [3].

Основною друкованою продукцією БМД є банкноти. Критерії системи якості банкнот досліджені науковцями, сформовано комплексну оцінку якості [4], розроблено узагальнену ієрархічну модель формування якості банкнот, встановлено критерії якості банкнотної продукції (захищеність, зносостійкість, розпізнаваність, машиночитаність, естетична прийнятність, технологічність, безпечність). Ці кри- 
терії дають змогу визначити оптимальні засоби формування якості банкнот [5].

Також розглянуто якість відбитків, отриманих у процесі металографічного друку. Серед показників якості можна виділити комплексні, групові та одиночні. Фактори впливу на якість відбитків металографічного друку - це технологічні режими друку, характеристики друкарської форми та друкарсько-технічні властивості матеріалів, задіяних у процесі друку [6].

Як уже зазначено вище, дослідження БМД світу щодо випуску друкованої сувенірної продукції лише розпочинаються. Уже розроблено класифікацію зображень, яку розглянуто за такими показниками: вибір технологічного способу друку та іх кількості, використання захисних елементів, підстава до випуску, ілюстративне наповнення, композиція, кількість кольорів та стиль [7]. Головною передумовою однак має бути автентичність друку, що можлива лише на обладнанні БМД.

В цілому друковану сувенірну продукцію можна поділити за ціновими критеріями на масову, корпоративну (бізнес-сувеніри) та сувеніри для VIP-клієнтів. Якість продукції залежить від якості сировини й матеріалів, рівня розвитку науки й технології, прогресивності застосування технологій, організації праці й виробництва та кваліфікації кадрів. Показники можуть бути одиничними та комплексними.

Наразі критерії якості до друкованої сувенірної продукції, що виготовляють БМД, не виокрем- лено та не доведено до єдиної системи. Тому визначення основних критеріїв якості та створення системи її формування їх забезпечення було одним з головних завдань дослідження.

\section{Результати проведених досліджень}

Для вирішення проблеми було застосовано метод аналізу ієрархій (MAI) [8] - математичний інструмент системного підходу до складних проблем прийняття рішень, що розроблений американським математиком Томасом Сааті. Глобальною метою $є$ якість виготовлення друкованої сувенірної продукції, а нижчі рівні впливають на формування вищих. Модель містить три рівні: критерії якості, дії акторів та актори.

Критеріями якості якісної друкованої сувенірної продукції БМД є виготовлення, актуальність, художня цінність, естетична прийнятність, технологічність, утилітарність. Критерії виготовлення мають такі підкритерії: якість матеріалів (паперу, фарби, паковання), якість друку (офсетного, інтагліо, трафаретного або їх комбінацій), захист (захисні елементи, нумерація, лазерне гравіювання), що робить друкований сувенір автентичним, підтверджує виготовлення на БМД та унеможливлює несанкціоноване копіювання. Підкритерії актуальності є запорукою попиту, головні критерії якості при цьому - новизна, традиційність, глибина й повнота теми, наявність цільової аудиторії та попит з її боку. Підкри- 
терії художньої цінності - це імітація класичних технік виготовлення (гравюра, офорт, рукопис та ін.), сучасні способи виготовлення, Ф'южин (поєднання абсолютно різних ідей, несумісних стилів, без втрати при цьому цілісності й гармонії), копії історично цінних документів, колекційна цінність (лімітованість накладу, серійність). До підкритеріїв якості естетичної прийнятності можна зарахувати колір, зображення, розмір, стиль, композицію, спосіб виконання, розкриття теми. Підкритеріями технологічності є підготовка виробництва, виробництво, встановлення автентичності, поширення. Останнім критерієм якості є утилітарність, що має підкритерії: колекціонування, використання в інтер'єрі. Утилітарність має іміджевий характер і передбачає паковання в стилі виробу.

Другий рівень ієрархії - дії акторів - це дії, що дозволяють формувати певний рівень якості: дизайн, виробничі заходи, інформаційні заходи. Підкритеріями дизайну $є$ композиція, розмір, колірне та графічне вирішення, стиль і стилізація зображення. Підкритеріями виробничих заходів $є$ технологічний процес, матеріали, обладнання, персонал, система управління якістю та поширення. До підкритеріїв інформаційних заходів належать розробка та впровадження, маркетингові заходи, вихід на ринок, зворотній зв'язок з колекціонерами та запобігання несанкціонованому копіюванню.

Третім рівнем ієрархії - рівнем акторів - $є$ суб'єкти, котрі через свої дії забезпечують відповідність якості певним критеріям. Цими акторами є розробник, виробник, постачальник, система продажу та цільова аудиторія. Розробник - це замовник і дизайнер. Виробник відповідальний за основу, друкування, паковання. Постачальник відповідальний за обладнання, матеріали та комплектуючі. Система продажу - це спеціальні магазини, відділення банків, інтернет магазини, об'єднання колекціонерів. Цільова аудиторія - це колекціонери, поціновувачі мистецтва, бізнес-партнери, населення країни, туристи.

На основі такого підходу до аналізу системи забезпечення якості друкованої сувенірної продукції БМД розроблено узагальнену ієрархічну модель формування якості (рис.).

Альтернативами в такій системі можуть бути елементи нижчих рівнів (актори, дії акторів) чи варіанти виготовлення сувенірної продукції БМД.

\section{Висновки}

Створено узагальнену ієрархічну модель формування якості виробництва друкованої сувенірної продукції, що випускається БМД, яка дала змогу визначити критерії якості їх виготовлення (якість виготовлення, актуальність, художню цінність, естетичну прийнятність, технологічність, утилітарність), дій акторів та самих акторів, і дає можливість визначити напрями забезпечення якості виробництва друкованої сувенірної продукції. 


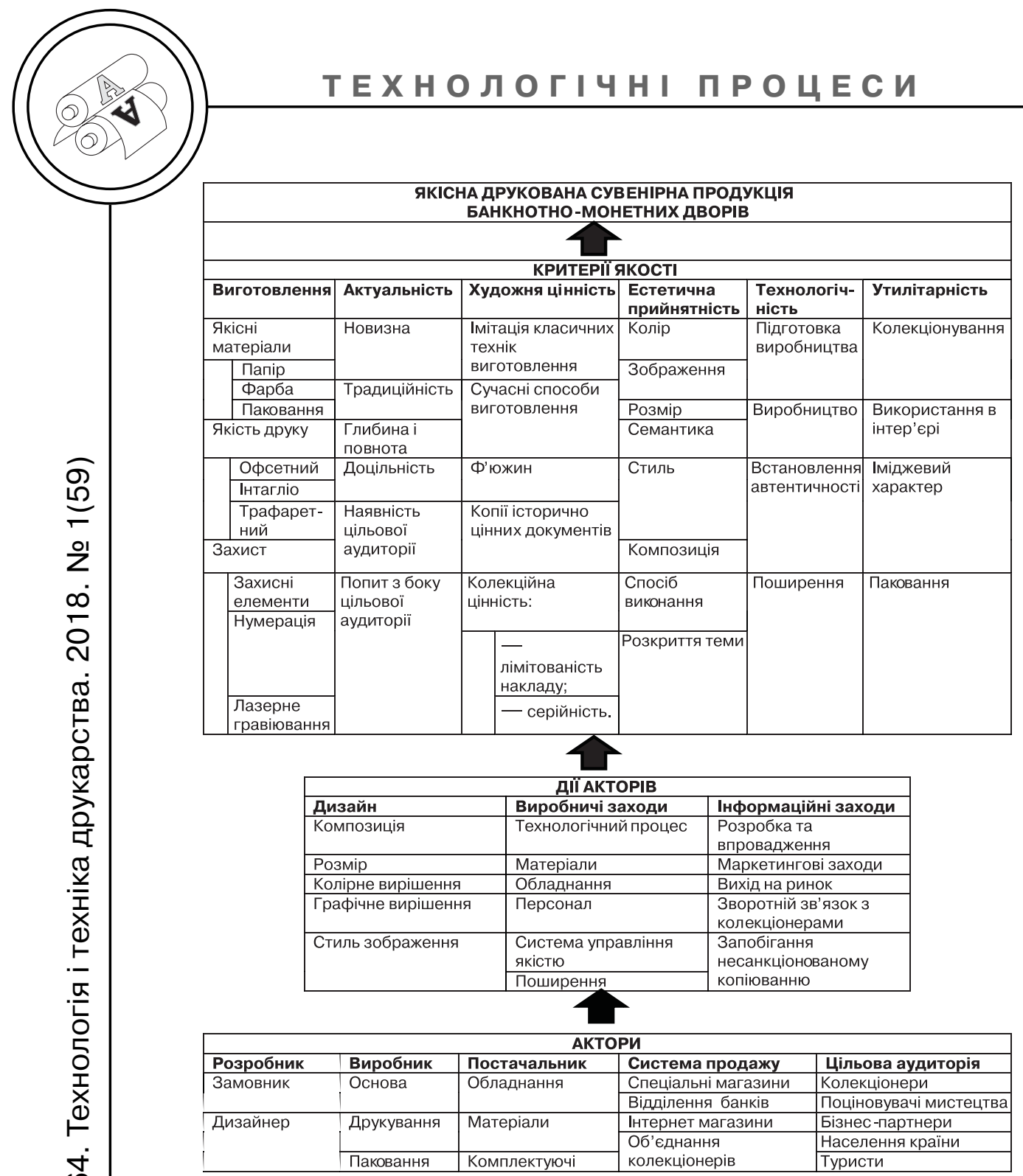

\section{Узагальнена ієрархічна модель формування системи якості виготовлення друкованої сувенірної продукції БМД}

\section{Список використаної літератури}

1. О. М. Величко. Опрацювання інформаційного потоку взаємодією елементів друкарського контакту: монографія / О. М. Величко. Київ: ВПЦ «Київський університет», 2005. С. 38.

2. Т. Ю. Киричок. Система забезпечення якості офсетного друку / Т. Ю. Киричок, Т. Є. Клименко // Технологія і техніка друкарства. 2015. № 1(47). С. 18-23. DOI: https://doi.org/10.20535/2077-7264.1(47).2015.43268.

3. Е. В. Коротенко. Систематизация показателей качества защищенной продукции / Е. В. Коротенко, Т. Е. Клименко // Скориновские чтения 2016: книга как феномен культуры, искусства, технологии: материалы II Международного форума, Минск, 6-7 сентября 2016 г. Минск: БГТУ, 2016. С. 191-195. 
4. Т. Ю. Киричок. Зносостійкість банкнотної продукції: монографія / Т. Ю. Киричок. К.: НТУУ «КПІ», 2014. 324 с.

5. Т. Ю. Киричок. Наукові основи забезпечення зносостійкості банкнотної продукції / Автореферат дисертації на здобуття наукового ступеня доктора технічних наук / Т. Ю. Киричок. Львів, 2014.

6. О. В. Коротенко. Технологічне забезпечення якості банкнот під час металографічного друку / Автореферат дисертації на здобуття наукового ступеня кандидата технічних наук / О. В. Коротенко. Київ. 2018.

7. Т. Ю. Киричок. Сучасні тенденції друкованої сувенірної продукції банкнотно-монетних дворів світу / Т. Ю. Киричок, Я. В. Герук // Технологія і техніка друкарства. К., 2017. № 2(56). С. 4-15. Режим доступу: http://ttdruk.vpi.kpi.ua/article/view/116233.

8. Саати Т. Л. Принятие решений. Метод анализа иерархий. М.: Радио и связь, 1989. 316 с.

\section{References}

1. Velychko, O. M. (2005). Opratsiuvannia informatsiinoho potoku vzaiemodiieiu elementiv drukarskoho kontaktu. Kyiv: VPTs 'Kyivskyi universytet', p. 38 [in Ukrainian].

2. Kyrychok, T. Yu. \& Klymenko, T. Ye. (2015). Systema zabezpechennia yakosti ofsetnoho druku. Journal of Tekhnolohiia i tekhnika drukarstva, 1(47), 18-23. DOI: https://doi.org/10.20535/2077-7264.1(47).2015.43268 [in Ukrainian].

3. Korotenko, E. V. \& Klimenko, T. E. (2016). Sistematizatsiya pokazateley kachestva zashchishchennoy produktsii. Journal of Skorinovskie chteniya 2016: kniga kak fenomen kul'tury, iskusstva, tekhnologii: materialy II Mezhdunarodnogo foruma. Minsk: BGTU [in Russian].

4. Kyrychok, T. Yu. (2014). Znosostiikist banknotnoi produktsii. Kyiv: NTUU 'KPI', 324 p. [in Ukrainian].

5. Kyrychok, T. Yu. (2014). Naukovi osnovy zabezpechennia znosostiikosti banknotnoi produktsii. Lviv [in Ukrainian].

6. Korotenko, O. V. (2018). Tekhnolohichne zabezpechennia yakosti banknot pid chas metalohrafichnoho druku. Kyiv [in Ukrainian].

7. Kyrychok, T. Yu. \& Heruk, Ya. V. (2017). Suchasni tendentsii drukovanoi suvenirnoi produktsii banknotno-monetnykh dvoriv svitu. Journal of Tekhnolohiia $i$ tekhnika drukarstva, 2(56), 4-15. Retrieved from http://ttdruk.vpi.kpi.ua/article/view/116233 [in Ukrainian].

8. Saati, T. L. (1989). Prinyatie resheniy. Metod analiza ierarkhiy. Moscow: Radio i svyaz', 316 p. [in Russian].

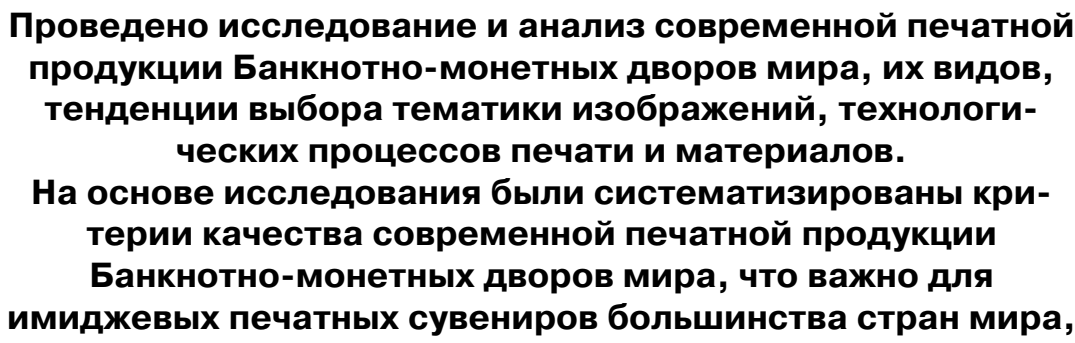

Проведено исследование и анализ современной печатной продукции Банкнотно-монетных дворов мира, их видов, ческих процессов печати и материалов.

На основе исследования были систематизированы критерии качества современной печатной продукции имиджевых печатных сувениров большинства стран мира, 
а прежде всего в Украине. Поэтому, развитие этой темы является современным, перспективным и конкурентоспособным.

Ключевые слова: качественная печатная сувенирная продукция; интаглиопечать; офорт; глубокая печать; изображение; Банкнотно-монетный двор.

Researches and analyisis of modern printed products emitted by the Banknotes and Mint of the world were conducted. Their types, tendency in the making choice of the subjects of images, technological processes of printing and materials were investigated as well. On the basis of the study, the quality criteria of the modern printed production of the Banknotes and Mint of the World were systematized, that is important for image printed souvenirs in most countries of the world, and above all in Ukraine. Therefore, the development of this topic is contemporary, promising and competitive.

Keywords: quality printed souvenirs; intaglio; etching; gravure printing; image; Banknote and Mint. 